\title{
Maximum Power Point Tracking Of Photovoltaic Module Using Golden Section Search Method
}

\author{
V. Sree Vidhya ${ }^{* 1}$, B. Rajasekhar ${ }^{\# 2}$, N. V. Prasanna ${ }^{* 3}$ K. Poojitha ${ }^{* 4}$ \\ *Electrical and Electronics Engineering, G. V. P. College Of Engineering For Women, India \\ "Electrical and Electronics Engineering, \\ Anil Neerukonda Institute of Technology and Sciences, India \\ ${ }^{1}$ sri.vydhyanadhan@gvpcew.ac.in \\ 2rajasekhar.balla@gmail.com \\ 3 nvp.prasanna@gmail.com \\ ${ }^{4}$ kpoojitha133@gmail.com
}

\begin{abstract}
The photovoltaic (PV) module has been the interface of electrical energy generation from the solar irradiation. The solar radiation, ambient temperature and solar cell temperature are not constant throughout the day. So, the maximum power condition varies all the time due to which the efficiency of PV cell decreases. To increase the efficiency of PV cell maximum power point tracking is used. Maximum Power Point Tracking (MPPT) is an algorithm that includes charge controller that is used for extracting maximum power available power from PV module under certain conditions. In addition to the above conditions, the irradiance on PV module is non-uniform due to shading of trees, clouds etc., called partial shading. Using conventional MPPT technique such as Perturb and Observe, Incremental conductance, Hill climbing it is not possible to track maximum power condition in partial shading condition. The main objective of the present work is to consider MPPT even during partial shading conditions such that the overall efficiency of the system is improved.

In this paper, a non-linear optimization technique called Golden Section Search (GSS) is used to track maximum power. The GSS method has the advantage of converging fast to extremum conditions even under partial shaded conditions.
\end{abstract}

A tool has been developed using MATLAB modelling the PV module operation under partial shading conditions and the result obtained is validated with existing work in the literature.

Keywords: Golden Section Search, Maximum Power Point Tracking, Partial shading

\section{INTRODUCTION}

Major sources for generating electricity are non-renewable energy sources such as coal, gas, nuclear etc. are extracted in large amount so their availability is reducing continuously. It takes more time to replenish these sources. So, it is necessary to choose the alternative sources called Renewable energy sources like sun, wind, biomass, tide, geothermal etc. which are always available in nature. The power generation from these sources is intermittent.

Solar power generation involves clean, noise less operation. The main component which generates electricity from the solar is the PV cell. The PV cell converts visible light into Direct current (DC) based on photovoltaic effect.

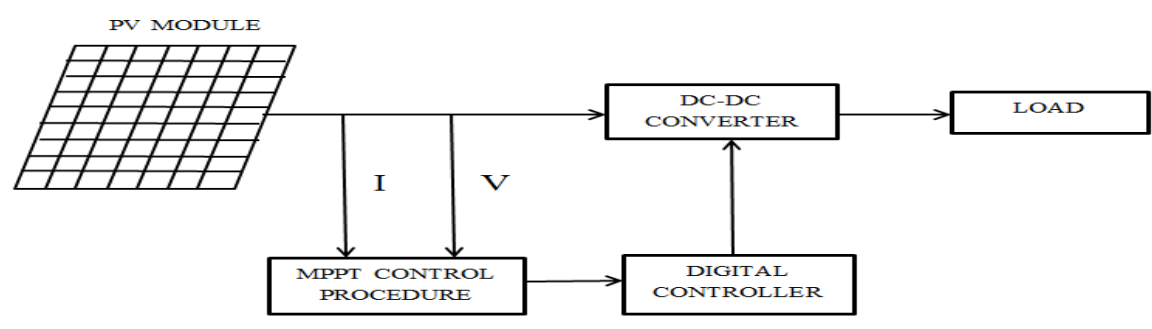

Figure1. Block diagram of PV system.

The main objective in designing the PV panel is to absorb the sunlight and convert it into required form of energy. To convert the obtained voltage from PV panel to the load voltage a DC-DC converter is used. For the system to operate at maximum efficiency, The MPPT charge controller takes the voltage from the PV panel and maximizes the amount of current flowing through the battery. 


\section{A. Classification of MPPT techniques: [3]}

The conventional methods do not track the maximum power under partial shaded conditions. An optimization technique is used to track maximum power under any conditions.

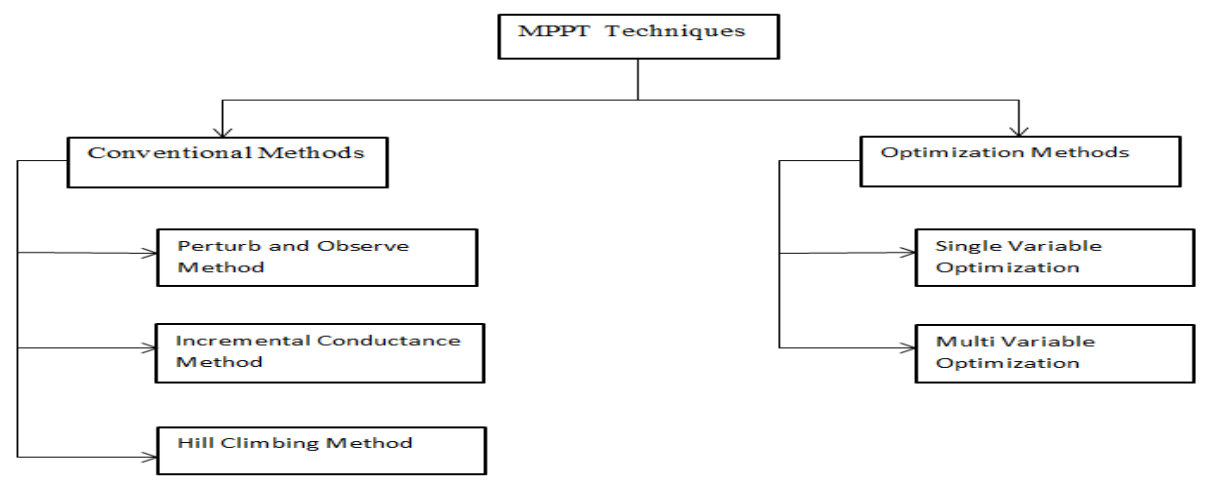

Figure 2: Classification of MPPT Techniques

\section{B. Effect of irradiance:}

The output from the solar panel depends on the environmental conditions such as irradiance, temperature etc. As the irradiance will not be consistent throughout day, the output of the solar panel also varies. The current generated from the solar panel is directly proportional to irradiance.

\section{Literature Review}

The amount of sunshine reaching the solar cells at any moment is referred to irradiance. The irradiance which reaches the earth will never be constant throughout the day due to movement of sun and clouds. Generally the irradiance that reaches the earth is $1000 \mathrm{~W} / \mathrm{m}^{2}$. The output of the PV panel depends on its position and amount of irradiance reaching module at that place. The position of PV module is not changing, with respect to sun's irradiance so variation in output is observed. So, it is necessary to track maximum power point in order to operate the PV module at maximum efficiency. An optimization technique called GSS is used to track maximum power under any external conditions. This is a non-linear elimination technique which tracks within few iterations and accurately.

\section{D.PV Cell Design:}

A PV cell is a special semiconductor diode that converts light energy (visible light) into direct current (DC). It is generally important to understand the behaviour of PV cell, so it is necessary to make the electrical equivalent circuit of a PV cell. [1]

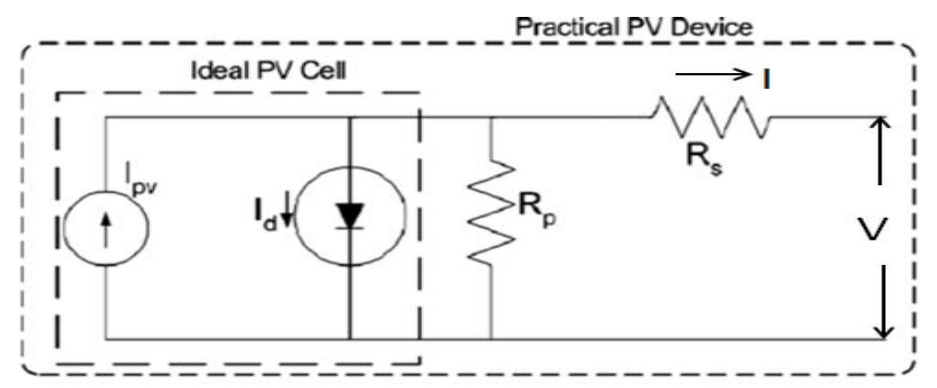

Figure 3: Equivalent circuit of PV cell

As shown in figure, the ideal cell can be analysed by having a current source in parallel to diode. But in practical, due to losses which are represented by a series and parallel resistances.

The output current (I) from the PV cell is desired as follows,

$\mathrm{I}=\mathrm{I}_{\mathrm{ph}}-\mathrm{I}_{\mathrm{d}}-\mathrm{I}_{\mathrm{p}}$

Where,

$\mathrm{I}_{\mathrm{ph}^{-}}$Photo current (A)

$\mathrm{I}_{d}$-Diode current (A)

$\mathrm{I}_{\mathrm{p}}$-Current through shunt resistance (A) 
$\mathrm{I}_{\mathrm{ph}}=\left(\frac{\mathrm{S}}{\mathrm{s}_{\mathrm{n}}}\right)\left[\mathrm{I}_{\mathrm{scn}}+\mathrm{k}_{\mathrm{i}}\left(\mathrm{T}-\mathrm{T}_{\mathrm{n}}\right)\right]$

Where,

S-Working irradiance $\left(\mathrm{W} / \mathrm{m}^{2}\right)$

$\mathrm{S}_{\mathrm{n}}$-Nominal irradiance $=1000 \mathrm{~W} / \mathrm{m}^{2}$

$\mathrm{I}_{\mathrm{scn}}$-Short circuit current at nominal conditions (A)

$\mathrm{k}_{\mathrm{i}}$-Short circuit current temperature coefficient $=0.0032 \mathrm{~A} /$ Kelvin

T-Standard temperature (Kelvin)

$\mathrm{T}_{\mathrm{n}}$-Nominal temperature (Kelvin)

$I_{d}=I_{0}\left[\exp \left(\left(V+R_{s} I\right) / V_{t} A\right)-1\right]$

Where,

$\mathrm{I}_{0}$-Diode saturation current $(\mathrm{A})$

V-Output voltage (V)

$\mathrm{R}_{\mathrm{S}}$-Series resistance $(\Omega)$

$\mathrm{V}_{\mathrm{t}}$-Thermal voltage $(\mathrm{V})$

$\mathrm{I}_{0}=\mathrm{I}_{0 \mathrm{n}}\left(\frac{T_{n}}{T}\right)^{3} \exp \left[\left(\frac{(\mathrm{qE})}{(\mathrm{AK})}\right)\left(\left(\frac{1}{\mathrm{~T}_{\mathrm{n}}}\right)-\left(\frac{1}{\mathrm{~T}}\right)\right)\right]$

Where,

$\mathrm{I}_{0 \mathrm{n}}$-Reverse saturation current (A)

$\mathrm{I}_{\mathrm{On}}=\left[\mathrm{I}_{\mathrm{scn}} / \exp \left(\mathrm{V}_{\mathrm{ocn}} /\left(\mathrm{AV_{ \textrm {tn } } )}\right)-1\right]\right.$

Where,

$\mathrm{V}_{\mathrm{ocn}}-$ Open circuit voltage at nominal conditions (V)

A- Diode ideality factor

$\mathrm{V}_{\mathrm{tn}}$-Thermal voltage at nominal conditions (v)

Current through the shunt resistance,

$\mathrm{I}_{\mathrm{p}}=\frac{\mathrm{V}+\mathrm{R}_{\mathrm{s}} \mathrm{I}}{\mathrm{R}_{p}}$

Where,

$\mathrm{R}_{\mathrm{p}}$-Parallel resistance

Output Current: $\mathrm{I}=\mathrm{I}_{\mathrm{ph}}-\mathrm{I}_{0}\left[\exp \left(\left(\mathrm{V}+\mathrm{R}_{\mathrm{s}} \mathrm{I}\right) /\left(\mathrm{V}_{\mathrm{t}} \mathrm{A}\right)\right)-1\right]-\left[\frac{\mathrm{V}+\mathrm{R}_{\mathrm{S}} \mathrm{I}}{\mathrm{R}_{\mathrm{p}}}\right]$

\section{Partial Shading Effect}

$\mathrm{PV}$ power generators are prone to electrical losses if the operating conditions are non-uniform such as in a case where part of the modules of a generator are shaded while the rest are receiving the global solar radiation. These conditions are called partial shading conditions and they have been recognized as a major cause of energy losses in PV power generation. [6], [7]. When one(or many) of the module in a solar panel comes under the effect of shading(which can be due to trees, buildings, clouds and many more), its voltage drops, so, it works as a load instead of working as a generator. The reverse bias on the solar cell, under extreme cases of shading, 
might exceed its breakdown voltage. In such cases, the cell gets fully damaged, develops cracks and an open circuit can occur at the serial branch where the cell is connected.

To avoid the power consumption of the shaded cells from the unshaded cells a bypass diode is used. Bypass diode:

Bypass diodes are used similar to that of freewheeling diode. These are kept in anti-parallel to a cell or panel so as to limit the current flow in opposite direction thereby preventing the damage of cell or panel. [8],[9]. Use of bypass diodes helps in supplying power at a reduced voltage rather than no power. Since the bypass diodes provide an alternate current path, cells does not carry the same current when they are partially shaded. So, the power-voltage curve develops multiple maxima.

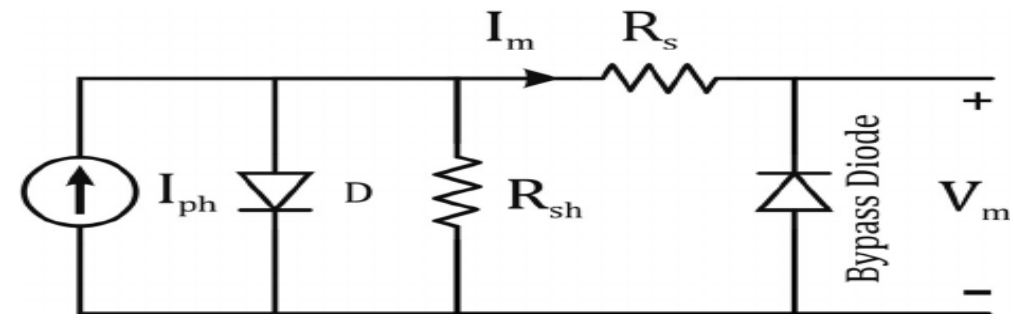

Figure 4: Practical PV cell model with bypass diode.

\section{GSS METHOD}

\section{A. Optimization:}

Optimization Techniques:

An optimization technique is used to optimize the given objective function. The procedure consists of finding the design variable values that results in the best objective function value, while satisfying all the equality, inequality and other constrains.

Advantages:

1. It yields the best solution within the domain of study.

2. Requires fewer experiments to achieve an optimum formulation.

3. It predicts the direction of improvement.

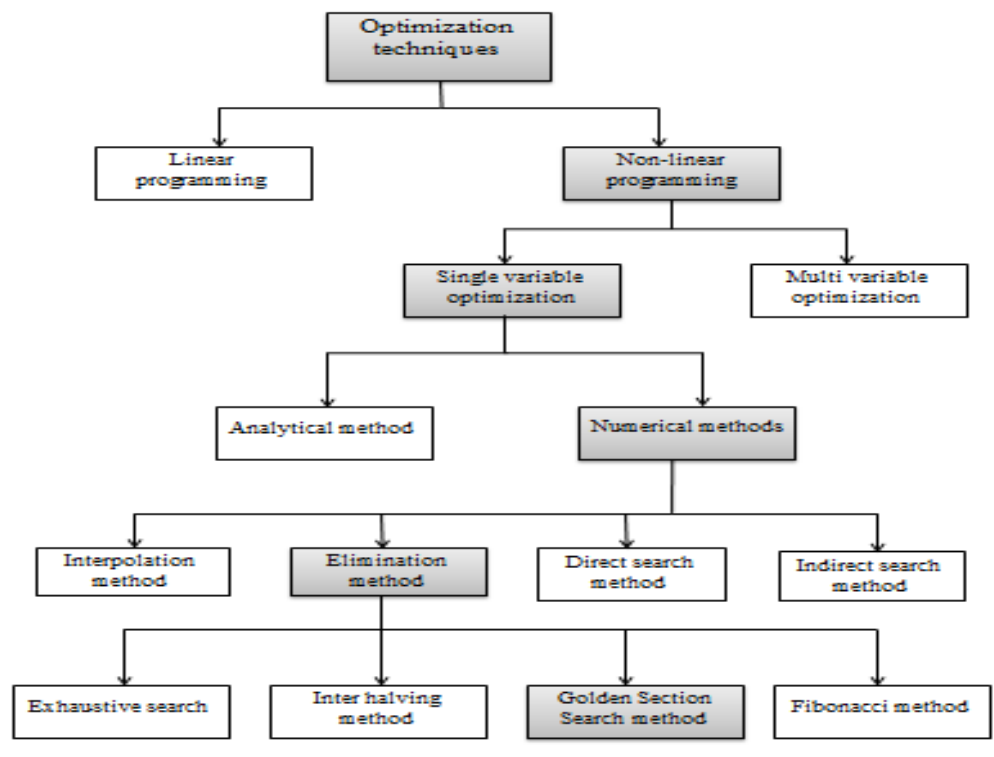

Figure5: Classification of Optimization techniques

Derivation of the Method of Golden Section Search:

Consider a continues and unimodal function ' $\mathrm{f}$ ' over a given interval $[\mathrm{a}, \mathrm{b}]$. A reduction factor is required for the search to get minimum iterations. [4], [5], [10] 


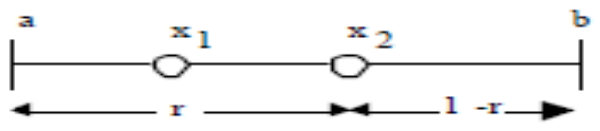

(a)

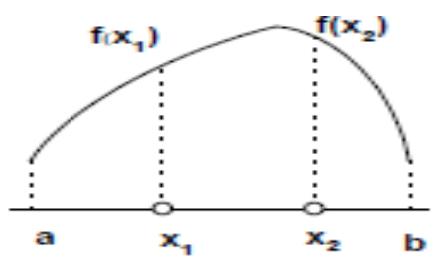

(b)

Figure6: (a) Division of interval (b): Interval as marking on the characteristics

We only want to perform one new function evaluation in each step. Also, we want a constant reduction factor, say $r$, for the size of the interval. For $\mathrm{x} 1$ and $\mathrm{x} 2$ somewhere in $[\mathrm{a}, \mathrm{b}]$, there are two cases:

1. If $\mathrm{f}(\mathrm{x} 1)>\mathrm{f}(\mathrm{x} 2)$, then $[\mathrm{a}, \mathrm{b}]:=[\mathrm{a}, \mathrm{x} 2]$

2. If $f(x 1)<f(x 2)$, then $[a, b]:=[x 1, b]$

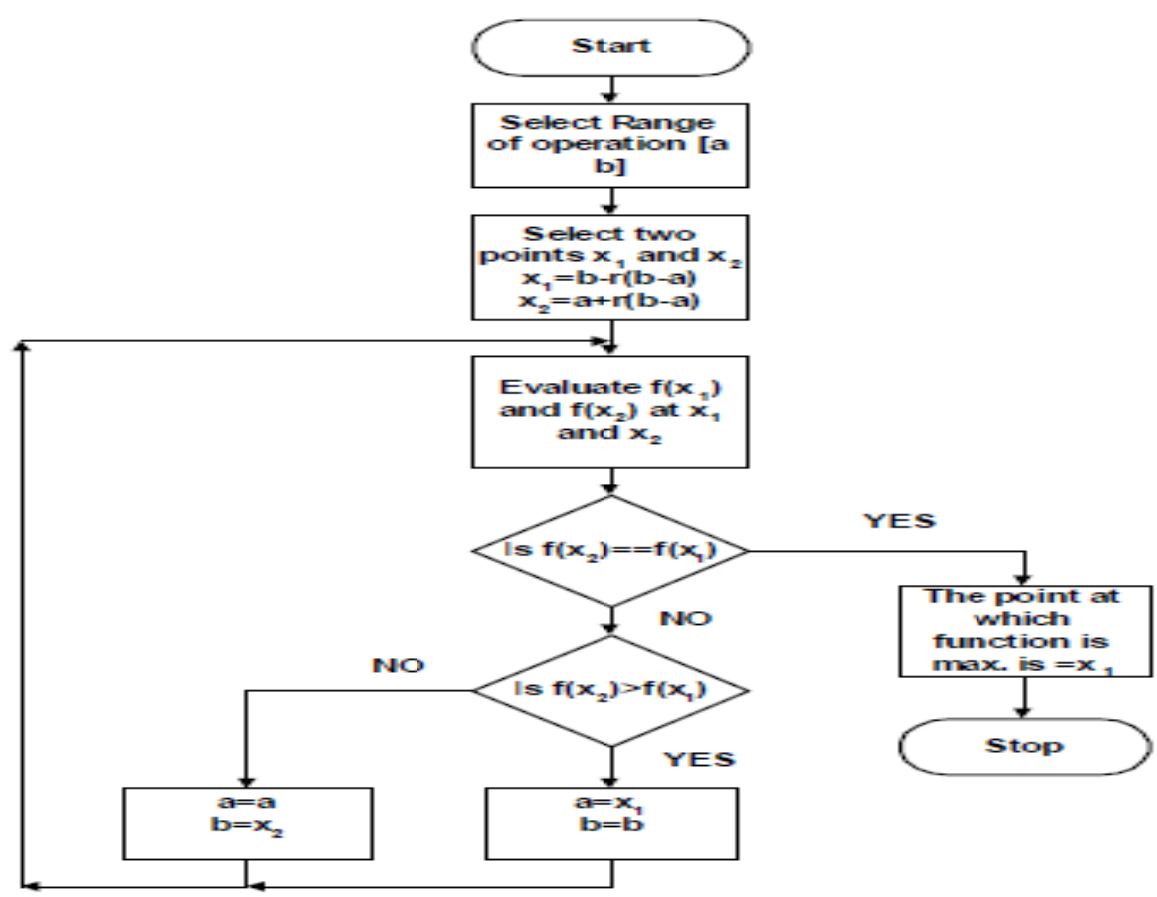

Figure 7: Flow chart representation of GSS method [2]

III.MATLAB RESULTS

Results obtained without using GSS Method:

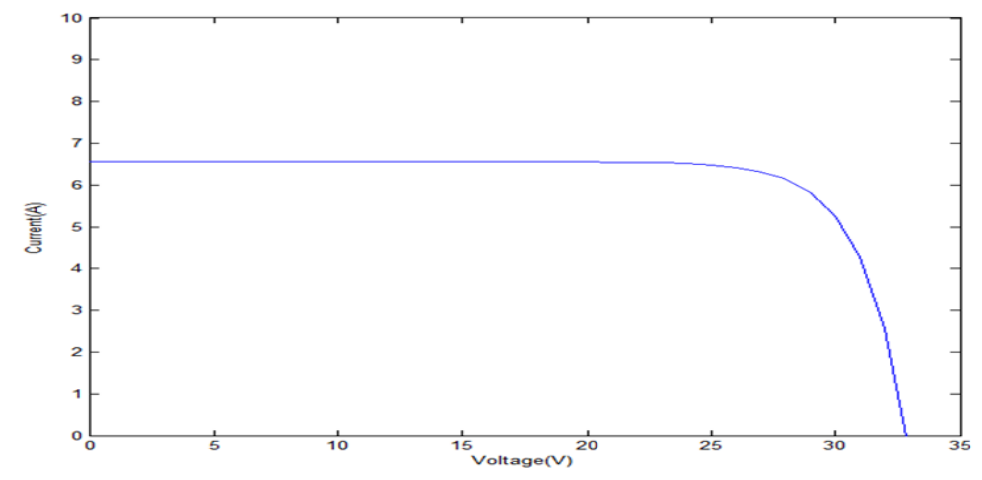

Figure8 (a): I-V characteristics of PV module at $800 \mathrm{~W} / \mathrm{m}^{2}$ 


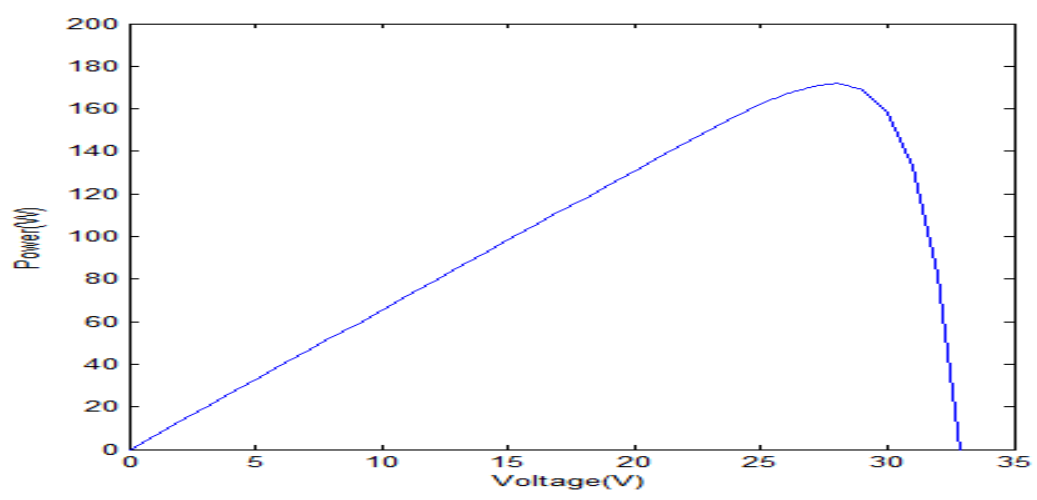

Figure8 (b): P-V characteristics of PV module at $800 \mathrm{~W} / \mathrm{m}^{2}$

The I-V curve starts from the Isc at zero volts, to zero current at the Voc. From zero to knee point, the charge from the PV panel is independent of output voltage. At the knee of the curve, the charge generation is not constant but starts to decrease. From knee point, recombination of charges increases and so the curve starts drooping. At Voc, all of the charges recombine internally and finally reaches zero.

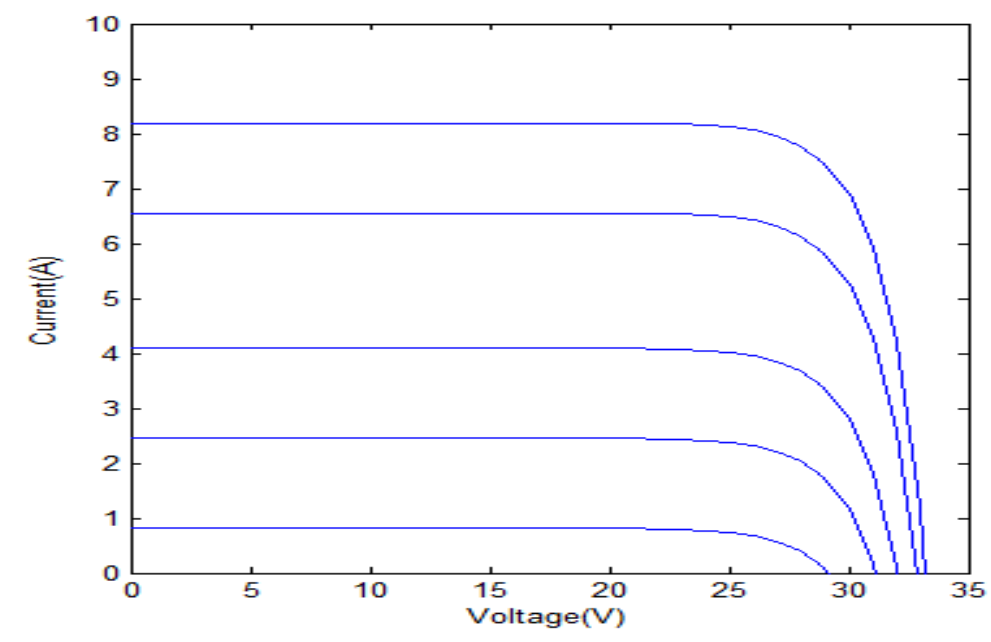

Figure 9 (a): I-V characteristics of PV module for different irradiance

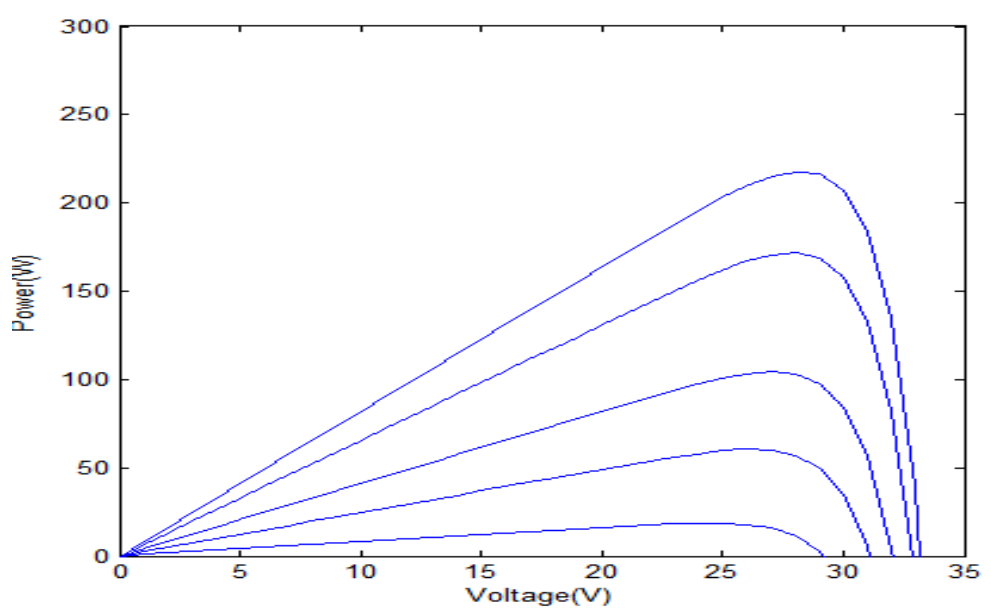

Figure 9 (b): P-V characteristics of PV module for different irradiance

With the variation in irradiance, there is a corresponding change in short circuit current i.e., as the irradiance increases short circuit current increases. The voltage variation is less when compared with current due to irradiance. 
Table1: Variation in open circuit voltage and short circuit current for different irradiance values

\begin{tabular}{|c|c|c|}
\hline Irradiance(W/m $\mathbf{2})$ & $\mathbf{V}_{\text {oc }}(\mathbf{V})$ & $\mathbf{I}_{\text {sc }}(\mathbf{A})$ \\
\hline 100 & 28 & 0.81 \\
\hline 300 & 30.5 & 3.1 \\
\hline 500 & 32.5 & 6.2 \\
\hline 800 & 32.5 & 7.4 \\
\hline 1000 & 32.5 & 8.2 \\
\hline
\end{tabular}

Results obtained Using GSS Method:

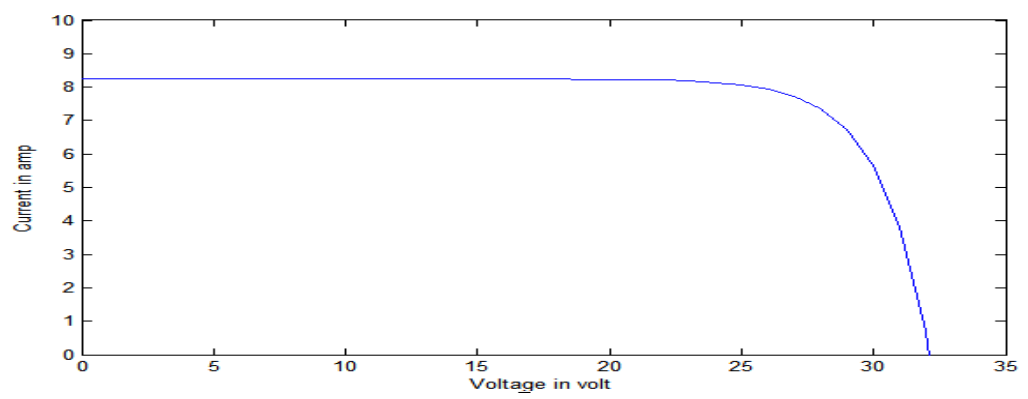

Figure 10(a): I-V characteristics of PV module for $1000 \mathrm{~W} / \mathrm{m}^{2}$

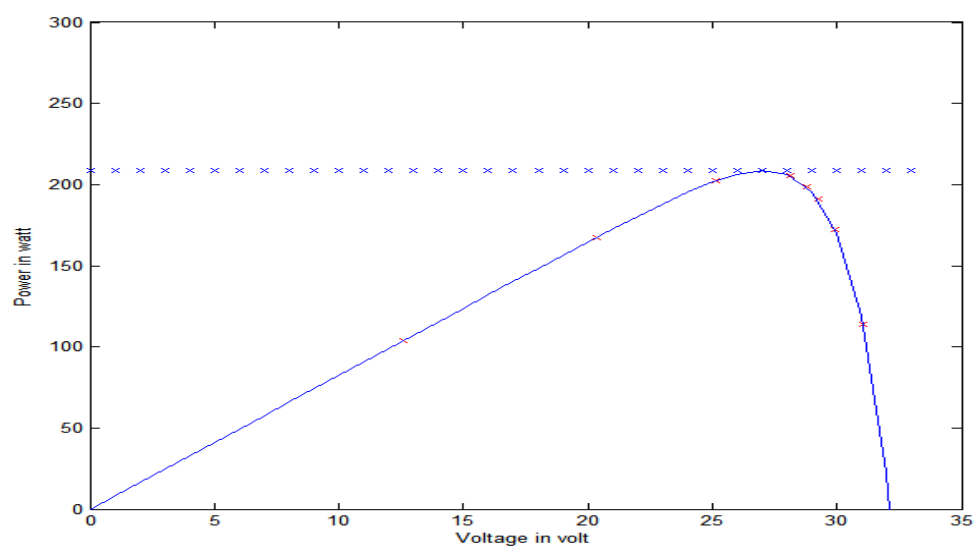

Figure 10(a): P-V characteristics of PV module for $1000 \mathrm{~W} / \mathrm{m}^{2}$

At the 'knee' of a normal I-V curve is the maximum power point (Impp, Vmpp), the point at which the array generates maximum electrical power. By GSS technique, for each iteration a part of section is eliminated and required knee point i.e., maximum power point is attained.

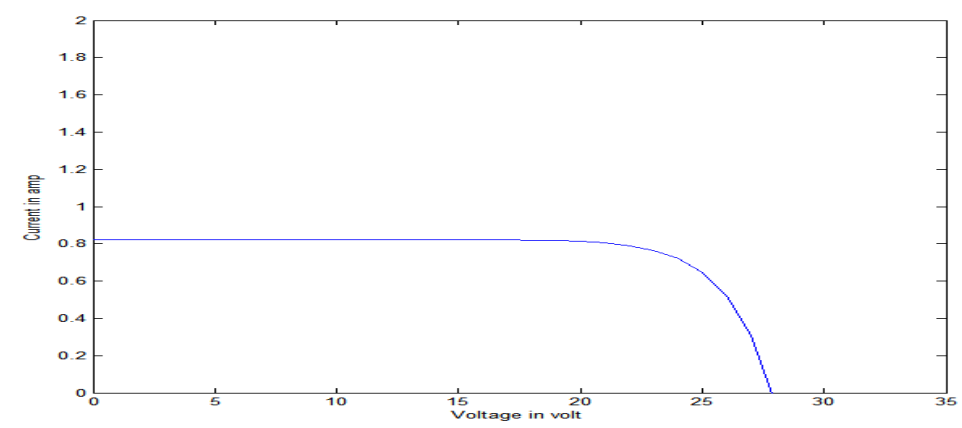

Figure 11(a): I-V characteristics of PV module for $100 \mathrm{~W} / \mathrm{m}^{2}$ 


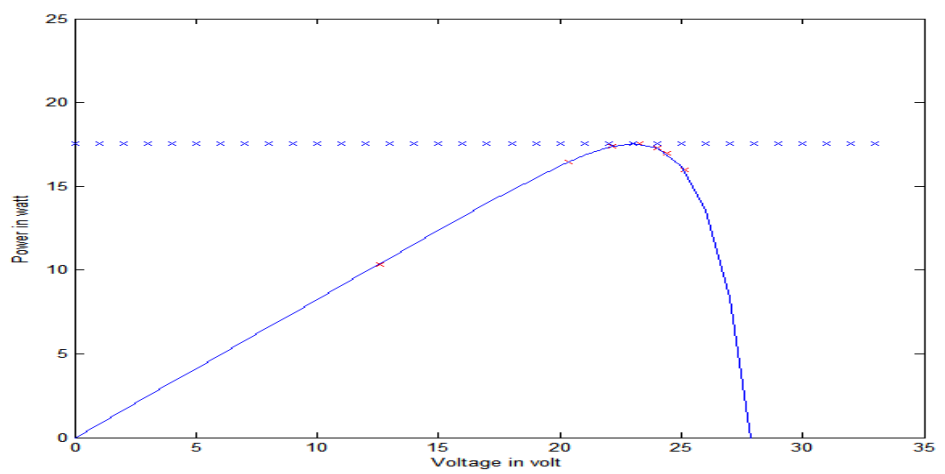

Figure 11(b): P-V characteristics of PV module for $100 \mathrm{~W} / \mathrm{m}^{2}$

Due to the decrease in irradiance, the current generated is decreased due to which the maximum power that is generated by the same module is also decreased.

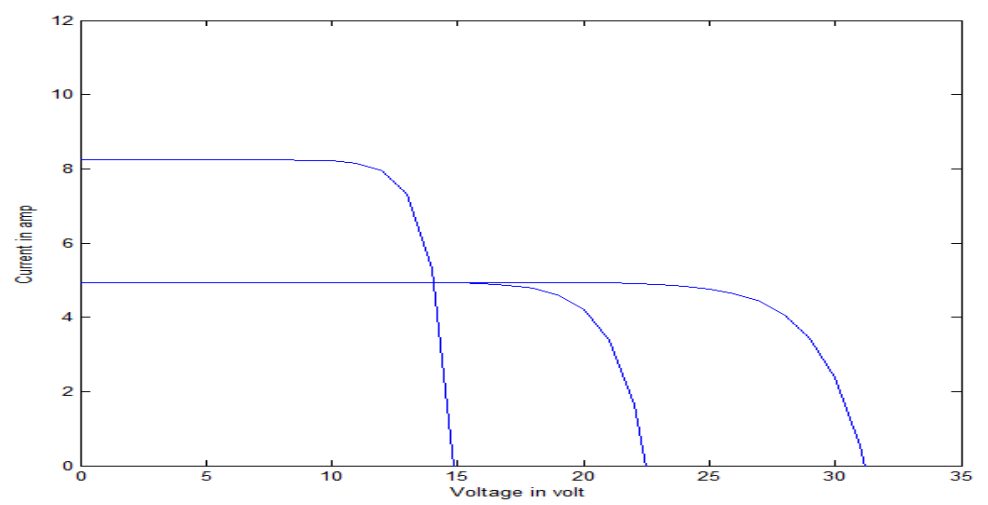

Figure 12(a) I-V characteristics of a PV module under partial shaded without bypass diode

Table 2: Variation of I-V curve under partial shaded conditions

\begin{tabular}{|c|c|c|}
\hline Irradiance( $\left.\mathbf{W} / \mathbf{m}^{2}\right)$ & $\mathrm{V}_{\text {oc }}(\mathbf{V})$ & $\mathrm{I}_{\mathbf{s c}}(\mathbf{A})$ \\
\hline $1000(25$ cells $)$ & 14.9 & 8.2 \\
\hline $600(39$ cells $)$ & 22.5 & 5 \\
\hline
\end{tabular}

Due to the effect of partial shading, there will be different irradiances on different group of cells of the same module. Due to this effect a great change is observed in voltage as the number of cells receiving the irradiance is decreased.

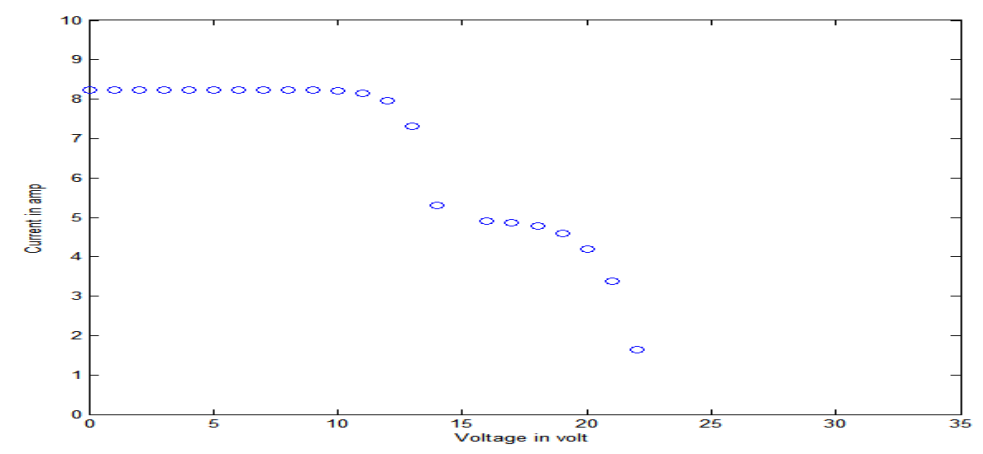

Figure12 (b): I-V characteristics of a PV module under partial shaded with bypass diode 


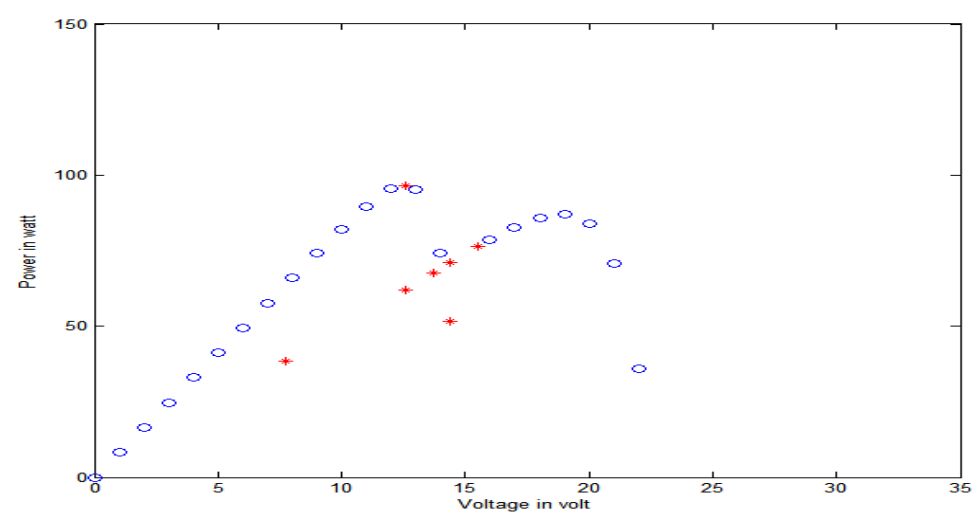

Figure12 (c): P-V characteristics of a PV module under partial shaded with bypass diode

Table 3: Maximum power point of PV module under partial shaded conditions

\begin{tabular}{|c|c|c|}
\hline $\begin{array}{c}\text { Irradiance } \\
\left(\mathbf{W} / \mathbf{m}^{2}\right)\end{array}$ & $\begin{array}{c}\mathrm{V}_{\mathrm{mpp}} \\
\text { (V) }\end{array}$ & $\begin{array}{c}\mathrm{P}_{\mathrm{mpp}} \\
\text { (W) }\end{array}$ \\
\cline { 1 - 2 } $1000(25$ cells $)$ & \multirow{2}{|c|}{12.5} & 95 \\
\cline { 1 - 1 } $600(39$ cells $)$ & 12.5 & 95 \\
\hline
\end{tabular}

Due to the effect of Bypass diode, there exist multiple peaks in output characteristics. The GSS method has shown its advantage by performing the search of maximum power point within 5 iterations even with multiple peaks.

\section{IV.CONCLUSION}

This paper concludes the design of PV module with 54 cells connected in series to generate a power of $210 \mathrm{~W}$ and $95 \mathrm{~W}$ under unshaded $\left(1000 \mathrm{~W} / \mathrm{m}^{2}\right)$ and partially shaded conditions respectively. Hence, GSS technique is used as the optimization method to track maximum power at unshaded and partially shaded conditions of the PV module which helps the system to converge in five iterations.

Table4: Characteristics of PV module under unshaded conditions:

\begin{tabular}{|l|l|l|l|l|l|}
\hline $\begin{array}{l}\text { Irradiance } \\
\left(\mathbf{W} / \mathbf{m}^{\mathbf{2}}\right)\end{array}$ & $\begin{array}{c}\mathrm{V}_{\mathrm{oc}} \\
(\mathbf{V})\end{array}$ & $\begin{array}{c}\mathrm{I}_{\mathrm{sc}} \\
(\mathbf{A})\end{array}$ & $\begin{array}{l}\mathrm{V}_{\mathrm{mpp}} \\
(\mathbf{V})\end{array}$ & $\begin{array}{c}\mathrm{P}_{\mathrm{mpp}} \\
(\mathbf{W})\end{array}$ & $\begin{array}{l}\text { Number of } \\
\text { iterations }\end{array}$ \\
\hline 1000 & 32 & 8.2 & 28 & 210 & 5 \\
\hline 100 & 28 & 0.81 & 23.3 & 17.5 & 5 \\
\hline
\end{tabular}

Table 5: The characteristics of PV module under partial shaded conditions:

\begin{tabular}{|c|c|c|c|c|}
\hline Irradiance $\left(\mathrm{W} / \mathrm{m}^{2}\right)$ & $\begin{array}{l}V_{\text {oc }} \\
\text { (V) }\end{array}$ & $\begin{array}{l}\mathrm{I}_{\mathrm{sc}} \\
\text { (A) }\end{array}$ & $\begin{array}{l}V_{\text {mpp }} \\
\text { (V) }\end{array}$ & $\begin{array}{l}\mathrm{P}_{\mathrm{mpp}} \\
\text { (W) }\end{array}$ \\
\hline 1000 ( 25 cells $)$ & 14.9 & 8.2 & \multirow[t]{2}{*}{12.5} & \multirow[t]{2}{*}{95} \\
\hline 600 (39 cells) & 22.5 & 5 & & \\
\hline
\end{tabular}

\section{REFERENCES}

[1] A detailed modelling of photovoltaic module using MATLAB Habbati Bellia, Ramdani Youcef, Moulay Fatima

[2] Comparative Study of Maximum Power PointTrackers for PV system,Malu Joseph,PG Student,Department of Electrical and Electronics Engineering,SXCCE, Nagercoil Tamilnadu, India.

[3] Energy Comparison of Seven MPPT Techniques for PV Systems A. Dolara, R. Faranda, S. LEVA ,Department of Energy of Politecnico di Milano, Via la Masa 34, 20156, Milano, Italy.

[4] Golden Section Search Optimization Technique For Maximum Power Point Tracking, Ajay Patel, Vikas Kumar, Yogendra Kumar / International Journal of Engineering Research and Applications (IJERA) ISSN: 2248-9622 www.ijera.com Vol. 3, Issue 2, March April 2013, pp.1204-1209 1204 .

[5] Golden Section Search (GSS) Algorithm for Maximum Power Point Tracking in Photovoltaic System, Jaya Agrawal, MohanAware,Member IEEE ,Electrical Engineering Department, Visvesvaraya National Institute of Technology, Nagpur, India.

[6] On the Impact of Partial Shading on PV Output Power, Dezso Sera Yahia Baghzouz ,Institute of Energy Technology Dept. of Electrical \& Computer Engr., Aalborg University

[7] A Comprehensive Review and Analysis of Solar Photovoltaic Array Configurations under Partial Shaded Conditions, R. Ramaprabha and B. L.Mathur, Department of EEE, SSN College of Engineering, Kalavakkam-603 110, Chennai, India. 
[8] Analytical Modeling of Partially Shaded Photovoltaic Systems Mohammadmehdi Seyedmahmoudian, Saad Mekhilef, Rasoul Rahmani, Rubiyah Yusof and Ehsan Taslimi Renani

[9] Partial Shading of PV System Simulation with Experimental Results, Basim A. Alsayid, Samer Y. Alsadi, Ja'far S. Jallad, Muhammad H. Dradi,Department of Electrical Engineering, Palestine Technical University-Kadoorie, Tulkarm, Palestine.

[10] Design and Implementation of Three-Level DC-DC Converter with Golden Section Search Based MPPT for the Photovoltaic Applications, Chouki Balakishan, N. Sandeep and M.V.Aware. 